\title{
Bioavailability of Essential Minerals from Staples Commonly Consumed in the Tropics
}

\author{
Lowell L. Dilworth $^{1}$, Kesi J. Brown ${ }^{2} \&$ Helen N. Asemota ${ }^{2}$ \\ ${ }^{1}$ Department of Pathology, University of the West Indies, Mona Campus, Jamaica \\ ${ }^{2}$ Department of Basic Medical Sciences, Biochemistry Section, University of the West Indies, Mona Campus, \\ Jamaica \\ Correspondence: Lowell Dilworth, Department of Pathology, University of the West Indies, Mona Campus, \\ Jamaica. Tel: 1-876-927-1410. E-mail: lowell.dilworth@uwimona.edu.jm
}

Received: November 12, 2012 Accepted: February 27, 2013 Online Published: March 20, 2013

doi:10.5539/jfr.v2n2p83

URL: http://dx.doi.org/10.5539/jfr.v2n2p83

\begin{abstract}
This study assessed essential minerals in sweet cassava (Manihot esculenta), Lucea yam (Dioscorea rotundata), plantain (Musa sp.) and pumpkin (Cucurbita pepo) by atomic absorption spectrophotometry while mineral bioavailabilities were assessed by in vitro enzymatic digestion.

Undigested cassava samples displayed highest calcium concentrations $(3150 \pm 320 \mathrm{mg} / \mathrm{Kg})$ while the highest iron concentrations were recorded in pumpkin samples $(81.5 \pm 4.7 \mathrm{mg} / \mathrm{Kg})$. Magnesium concentrations were highest in ripe plantain samples $(963 \pm 15.18 \mathrm{mg} / \mathrm{Kg})$ while the highest zinc concentrations were recorded in cassava $(15.23 \pm 4.07 \mathrm{mg} / \mathrm{Kg})$. Cooked samples displayed higher percentages of available minerals than uncooked ones with unripe plantain displaying highest percentage soluble calcium (12.945), iron (37.19\%) and magnesium (23.37\%) while the highest percentage soluble zinc was observed in sweet cassava (9.87\%).

The samples assessed are important contributors of essential dietary minerals especially in the cooked states. These staples have untapped potential for increased economic relevance especially with increasing costs of food production. Studies aimed at increasing mineral bioavailability in some samples are needed.
\end{abstract}

Keywords: cooking, in vitro, tubers, bioaccessibility, mineral

\section{Introduction}

Some of the most commonly consumed staple crops worldwide are cereals including rice, barley, wheat and maize. In addition, yams (Dioscorea spp.), cassava (Manihot esculenta), plantain (Musa spp. AAB group), pumpkin (Cucurbita pepo), breadfruit (Artocarpus altilis) and other starchy foods are also commonly consumed in many regions of Asia, Africa and the Caribbean (Etebu \& Young-Harry, 2011; Ogunlade et al., 2011; Dilworth et al., 2012).

Yams are dynamic staple foods and can be made edible by various preparation methods including frying, boiling, baking and roasting. In many countries, its demand has always outstripped supply with one contributory factor being post-harvest losses (Amusa et al., 2003). Nevertheless, yam production contributes significantly to export income of the Caribbean; with a value exceeding US\$18,000,000 in 1997 (Beckford et al., 2011). The yam varieties most widely cultivated and consumed throughout the region include Yellow yam, St. Vincent, Lucea and Renta varieties, with most research focus placed on Yellow yam.

In many Caribbean countries, cassava is not regarded as a major export crop, however, the by-products of the sweet and bitter varieties inclusive of cassava chips and bammy respectively, are important contributors to the diets of many persons (Essono et al., 2008). The crop is of great economic importance to many tropical countries, owing to its high nutrient content and resistance to drought and pests (Oboh, 2005). In some areas, there are concerns regarding potential impact of high cyanine content of by-products if their processing methods are inadequate. Modern quality control methods however ensure that these incidences remain low or non-existent. As a result, cassava and its by-products remain popular among consumers.

Plantains are a rich source of carbohydrates, dietary fibre and micronutrients and serve as an important food crop for millions of people who reside in tropical and sub-tropical areas (Honfo et al., 2011). It is a versatile crop that 
may be processed in numerous ways, either the ripe or unripe state, prior to consumption. In addition to the nutrient value of the crop, research has also uncovered potential health benefits of its extracts that contain a wide variety of bioactive compounds with high therapeutic antioxidant activities (Akinmoladun et al., 2007). Recent research also highlights positive effects of plantain meals on glycaemic indices of healthy individuals (Ayodele \& Godwin, 2010).

Pumpkin, a highly nutritious crop, contains high levels of protein, minerals and amino acids. By-products including seeds are also valued for their high nutrient value (Ndoro et al., 2007; Dilworth et al., 2012). Research shows that numerous pharmacological activities, including anti-carcinogenic and lipid lowering properties, are attributable to this versatile crop (Hong, 2005; Makni et al., 2008). Pumpkins, in addition to plantains, cassava and yams, are valuable components to the diets of persons living in the tropics and sub-tropical regions.

Bioavailability refers to the portion of minerals in foods that is available for utilisation for normal metabolism (Fairweather-Tait, 1992). Numerous factors contribute to mineral bioavailability including structure; size and weight of the mineral; presence of mineral-chelating factors within the food source; and health status of an individual. The food crops assessed in this study are shown to be high in some essential minerals, however, mineral bioavailability from cooked and uncooked samples needs to be assessed, since this information indicates the percentage of mineral available for absorption. The food samples selected are of economic and nutritional interest as they make up a large portion of the carbohydrate component of the diets of numerous individuals especially those residing in tropical and subtropical areas. This research is therefore aimed at assessing the bioavailability of some essential minerals from commonly eaten tropical staple crops following in vitro digestion. Research in this regard is geared at providing valuable information that will aid in facilitating increased production of these and other staples, leading to improved food security, specifically in regions where under-nutrition is a cause for concern.

\section{Methodology}

\subsection{Materials}

Fresh matured samples of Lucea yam (D. rotundata), Sweet cassava (Manihot esculenta), Plantain (Musa spp AAB group) and Pumpkin (Cucurbita pepo) were collected from a farm in the parish of Trelawny, central Jamaica. Samples were collected in the summer months of June to August. Once collected, samples were stored on ice and transported to the lab where they were washed, peeled (to remove inedible parts), diced and oven-dried to constant weight at $40^{\circ} \mathrm{C}$. After dicing, replicate samples were also cooked by boiling at atmospheric pressure for 15 minutes in a 10 fold $(\mathrm{v} / \mathrm{w})$ of deionised water followed by oven drying. All samples were then crushed in a laboratory mill (Cole-Parmer IKA Continuous feed grinding mill, EW-04301-30, Chicago Illinois USA) mesh size $0.2 \mathrm{~mm}$ and frozen for further use. Results are reported as milligrams per Kilogram of dry weight. All samples were collected and assessed in triplicates.

\subsection{Analytical Methods}

Calcium, magnesium, zinc and iron were determined by standard atomic absorption spectrophotometeric methods (AOAC, 2000). Samples were ashed, acid digested and taken to solution in deionised water. A nitrous oxide/acetylene mixture was used and minerals were assessed at the following wavelengths; calcium $422.7 \mathrm{~nm}$, iron $248.3 \mathrm{~nm}$, zinc $213.9 \mathrm{~nm}$ and copper $327.7 \mathrm{~nm}$. In assessing calcium and zinc, $0.7 \mathrm{~nm}$ slit width was used while $0.2 \mathrm{~nm}$ was used for assessing iron and magnesium. When determining calcium content, a solution of lanthanum chloride was added to all samples, including the reference samples, to attain a $0.5 \% \mathrm{La}^{3+}$ concentration. The accuracy of the analytical method was confirmed through a series of certified analyses of reference materials. Appropriate spikes were added to specific samples for recovery determination. Samples were read using a Unicam 939 atomic absorption spectrophotometer equipped with background correction lamps.

\subsection{Enzymatic Digestion}

The availability of minerals from these commonly eaten tuber crops was assessed after in vitro enzymatic digestion followed by further analyses of the residues and filtrates. The degree of release of minerals during in vitro digestion was carried out according to the method of Ikeda (1990) with modifications. De-ionised water (10 $\mathrm{mL}$ ) was added to $1.0 \mathrm{~g}$ of sample and supplemented with sodium azide to a final concentration of $0.025 \%$. The solution was then brought to $\mathrm{pH} 2.0$ with $1 \mathrm{M} \mathrm{HCl}$ after which pepsin solution was added at the level of $0.5 \mathrm{~g}$ enzyme per $100 \mathrm{~g}$. Incubation of the samples followed at $37^{\circ} \mathrm{C}$ for 2 hours. The $\mathrm{pH}$ of the solutions were monitored during this period and adjusted by adding $2 \mathrm{M} \mathrm{HCl}$ where necessary. After the incubation period, the $\mathrm{pH}$ of the solutions was raised to $6.8-7.0$ by adding $6 \% \mathrm{NaHCO}_{3}$ solution. A solution of pancreatin $(0.4 \%)$ was 
added at the rate of $10 \mathrm{ml}$ per $40 \mathrm{~mL}$ of sample solution, followed by incubation for 4 hours. The mineralized sample was centrifuged at $4000 \mathrm{rpm}$ for $30 \mathrm{~min}$ and decanted by draining through medium-hardness paper. Ashing of the sample was done as described earlier and the filtrates were also analyzed for their mineral contents. The percentage soluble minerals represent their bioavailability expressed as: concentration of minerals in the filtrate (soluble fraction) as a percentage of total minerals in the digested sample.

\subsection{Statistical Analyses}

Results were expressed as means \pm Standard Error of the Mean (SEM). Statistical Package for the Social Sciences (SPSS) version 16.0 was used for one way Analysis of variance tests to assess significant difference among samples. Duncan's Multiple Range Test was used to test for significant difference among the means and a cutoff $p$ value $<0.05$ was taken as significant (Sokal \& Rolf, 1969, 1994).

\section{Results}

\subsection{Calcium}

Table 1. Calcium concentrations in digested and undigested samples of four staples in cooked and uncooked states

\begin{tabular}{|c|c|c|c|c|c|c|}
\hline \multirow{3}{*}{ Food Samples } & \multicolumn{6}{|c|}{ Calcium Content (mg/Kg dry weight) } \\
\hline & \multicolumn{2}{|c|}{ Undigested } & \multicolumn{2}{|c|}{ Digested } & \multicolumn{2}{|c|}{ Filtrate } \\
\hline & Uncooked & Cooked & Uncooked & Cooked & Uncooked & Cooked \\
\hline $\begin{array}{l}\text { Dioscorea } \\
\text { rotundata } \\
\text { (Lucea yam) }\end{array}$ & $\begin{array}{c}1800.1 \pm \\
200.2^{\mathrm{a}}\end{array}$ & $\begin{array}{c}1645.2 \pm \\
150.7^{\mathrm{a}}\end{array}$ & $\begin{array}{c}1600.3^{ \pm} \\
100.8^{\mathrm{c}}\end{array}$ & $\begin{array}{c}1350.7 \pm \\
150.8^{\mathrm{d}}\end{array}$ & $74.3 \pm 5.5^{\mathrm{e}}$ & $98.2 \pm 7.5^{\mathrm{f}}$ \\
\hline $\begin{array}{l}\text { Manihot } \\
\text { esculenta } \\
\text { (Sweet cassava) }\end{array}$ & $\begin{array}{c}3150.2 \pm \\
320.4^{\mathrm{a}}\end{array}$ & $\begin{array}{c}3050.9 \pm \\
100.6^{\mathrm{a}}\end{array}$ & $\begin{array}{c}2800.2^{ \pm} \\
180.1^{\mathrm{c}}\end{array}$ & $\begin{array}{c}2800.4^{ \pm} \\
200.9^{\mathrm{c}}\end{array}$ & $54.9 \pm 5.5^{\mathrm{e}}$ & $79.2 \pm 10.1^{\mathrm{f}}$ \\
\hline $\begin{array}{l}\text { Musa spp. } \\
\text { (Plantain-ripe) }\end{array}$ & $\begin{array}{c}1950.4 \pm \\
150.8^{\mathrm{a}}\end{array}$ & $\begin{array}{c}1350.1^{ \pm} \\
250.4^{\mathrm{b}}\end{array}$ & $\begin{array}{c}1650.6 \pm \\
200.9^{c}\end{array}$ & $\begin{array}{c}1250.8^{ \pm} \\
250.1^{\mathrm{c}}\end{array}$ & $40.3 \pm 7.9^{\mathrm{e}}$ & $47.5 \pm 7.5^{\mathrm{f}}$ \\
\hline $\begin{array}{l}\text { Musa spp. } \\
\text { (Plantain-unripe) }\end{array}$ & $\begin{array}{c}550.1 \pm \\
50.6^{\mathrm{a}}\end{array}$ & $450.9 \pm 50.4^{\mathrm{a}}$ & $\begin{array}{l}450.8 \pm \\
100.6^{c}\end{array}$ & $\begin{array}{c}350.7 \pm \\
50.6^{\mathrm{c}}\end{array}$ & $50.4 \pm 0.5^{\mathrm{e}}$ & $45.3 \pm 3.1^{\mathrm{e}}$ \\
\hline $\begin{array}{l}\text { Cucurbita pepo } \\
\text { (Pumpkin) }\end{array}$ & $\begin{array}{c}1645.8 \pm \\
250.1^{\mathrm{a}}\end{array}$ & $\begin{array}{c}1720.1 \pm \\
20.1^{\mathrm{a}}\end{array}$ & $\begin{array}{c}1450.7^{ \pm} \\
150.4^{\mathrm{c}}\end{array}$ & $\begin{array}{c}1310.5 \pm \\
300.2^{\mathrm{c}}\end{array}$ & $63.5 \pm 7.1^{\mathrm{e}}$ & $82.7 \pm 3.6^{\mathrm{f}}$ \\
\hline
\end{tabular}

Values are expressed as mean \pm SEM where $n=4$. Values with different letter superscripts are significantly different, $\mathrm{P}<0.05, \mathrm{n}=3$. Statistical comparisons were carried out between cooked and uncooked undigested food sample.

Calcium content of undigested samples was assessed in the cooked and uncooked states as highlighted in Table 1. This assessment serves as a good indicator of the amount of minerals in processed versus unprocessed food samples. Calcium content of undigested uncooked Lucea yam and ripe plantain samples were significantly higher than values observed in the corresponding cooked samples.

Calcium content of cooked and uncooked digested sweet cassava were similar $(2800 \pm 200$ and $2800 \pm 180$ $\mathrm{mg} / \mathrm{Kg}$ respectively) while significant variations were observed in digested cooked and uncooked samples of Lucea yam $(1350 \pm 150 \mathrm{mg} / \mathrm{Kg}$ and $1600 \pm 100 \mathrm{mg} / \mathrm{Kg})$ and ripe plantain $(1250 \pm 250$ and $1650 \pm 200 \mathrm{mg} / \mathrm{Kg})$. Calcium concentrations in digested unripe plantain as well as other samples did not vary significantly from each other.

Assessment of sample filtrates shows that in cooked samples, the highest percent of soluble calcium was observed in samples of unripe plantain (12.94\%), followed by Lucea yam (7.27\%) and pumpkin (6.32 \%). Other samples recorded lower soluble calcium. Variations were observed with percentage soluble calcium in uncooked samples with sweet cassava recording $1.96 \%$, ripe plantain recording $2.44 \%$, pumpkin samples with $4.36 \%$ and unripe plantain samples recording $11.2 \%$ of soluble calcium. 


\subsection{Iron}

Table 2. Iron concentrations in digested and undigested samples of four staples in cooked and uncooked states

\begin{tabular}{|c|c|c|c|c|c|c|}
\hline \multirow{3}{*}{ Food Samples } & \multicolumn{6}{|c|}{ Iron Content (mg/Kg dry weight) } \\
\hline & \multicolumn{2}{|c|}{ Undigested } & \multicolumn{2}{|c|}{ Digested } & \multicolumn{2}{|c|}{ Filtrate } \\
\hline & Uncooked & Cooked & Uncooked & Cooked & Uncooked & Cooked \\
\hline $\begin{array}{l}\text { Dioscorea rotundata } \\
\text { (Lucea yam) }\end{array}$ & $52.5 \pm 0.8^{\mathrm{a}}$ & $44.5 \pm 5.8^{\mathrm{b}}$ & $41.5 \pm 1.7^{\mathrm{c}}$ & $34.5 \pm 0.8^{\mathrm{d}}$ & $5.6 \pm 0.1^{\mathrm{e}}$ & $7.1 \pm 1.2^{\mathrm{f}}$ \\
\hline $\begin{array}{l}\text { Manihot esculenta } \\
\text { (Sweet cassava) }\end{array}$ & $58.2 \pm 0.8^{\mathrm{a}}$ & $36.1 \pm 0.5^{b}$ & $39.5 \pm 0.6^{\mathrm{c}}$ & $23.9 \pm 0.3^{\mathrm{d}}$ & $8.8 \pm 2.4$ & $5.4 \pm 0.5$ \\
\hline $\begin{array}{l}\text { Musa spp. } \\
\text { (Plantain-ripe) }\end{array}$ & $56.5 \pm 0.5^{\mathrm{a}}$ & $38.4 \pm 2.5^{\mathrm{b}}$ & $48.1 \pm 12.4^{c}$ & $28.6 \pm 1.4^{\mathrm{d}}$ & $4.2 \pm 0.6^{\mathrm{e}}$ & $6.6 \pm 2.2^{\mathrm{e}}$ \\
\hline $\begin{array}{l}\text { Musa spp. } \\
\text { (Plantain-unripe) }\end{array}$ & $60.0 \pm 2.4^{\mathrm{a}}$ & $53.8 \pm 6.0^{\mathrm{a}}$ & $49.5 \pm 2.7^{\mathrm{c}}$ & $37.1 \pm 4.4^{\mathrm{d}}$ & $7.4 \pm 0.4^{\mathrm{e}}$ & $13.8 \pm 0.3^{\mathrm{f}}$ \\
\hline $\begin{array}{l}\text { Cucurbita pepo } \\
\text { (Pumpkin) }\end{array}$ & $81.5 \pm 4.7^{\mathrm{a}}$ & $75.3 \pm 2.0^{\mathrm{a}}$ & $72.1 \pm 11.3^{c}$ & $57.3 \pm 12.5^{\mathrm{c}}$ & $9.7 \pm 0.2^{\mathrm{e}}$ & $9.98 \pm 0.4^{\mathrm{e}}$ \\
\hline
\end{tabular}

Values are expressed as mean \pm SEM where $\mathrm{n}=4$. Values with different letter superscripts are significantly different, $\mathrm{P}<0.05, \mathrm{n}=3$. Statistical comparisons were carried out between cooked and uncooked undigested food sample.

Table 2 shows that assessment of undigested samples revealed that iron concentrations in cooked samples were generally higher than levels seen in uncooked samples. Cooked samples of Lucea yam, sweet cassava and ripe plantain recorded values of $44.65 \pm 5.85 \mathrm{mg} / \mathrm{Kg}, 36.10 \pm 0.50 \mathrm{mg} / \mathrm{Kg}, 38.45 \pm 2.25 \mathrm{mg} / \mathrm{Kg}$ respectively while uncooked samples recorded values of $52.05 \pm 0.85 \mathrm{mg} / \mathrm{Kg}, 58.20 \pm 0.80 \mathrm{mg} / \mathrm{Kg}$ and $56.55 \pm 0.65 \mathrm{mg} / \mathrm{Kg} \mathrm{mg} / \mathrm{Kg}$ respectively.

Assessment of residues of cooked sample shows that following digestion, there was approximately $30 \%$ reduction in iron content of sweet cassava, ripe plantain, unripe plantain plantain and pumpkin samples while iron content in samples of Lucea yam was reduced by $21.72 \%$. The soluble iron content, as recorded in filtrates, showed that in cooked samples, Lucea yam recorded $20.23 \%$ soluble iron, $23.55 \%$ was recorded for sweet cassava, ripe plantain recorded $24.5 \%$, unripe plantain recorded $37.2 \%$, while pumpkin recorded $17.5 \%$. All cooked samples recorded higher percentage of soluble iron compared to uncooked samples.

\subsection{Magnesium}

Table 3. Magnesium concentrations in digested and undigested samples of four staples in cooked and uncooked states

\begin{tabular}{|c|c|c|c|c|c|c|}
\hline \multirow{3}{*}{ Food Samples } & \multicolumn{6}{|c|}{ Magnesium Content (mg/Kg dry weight) } \\
\hline & \multicolumn{2}{|c|}{ Undigested } & \multicolumn{2}{|c|}{ Digested } & \multicolumn{2}{|c|}{ Filtrate } \\
\hline & Uncooked & Cooked & Uncooked & Cooked & Uncooked & Cooked \\
\hline $\begin{array}{l}\text { Dioscorea } \\
\text { rotundata } \\
\text { (Lucea yam) }\end{array}$ & $780.1 \pm 36.1^{\mathrm{a}}$ & $350.8 \pm 22.3^{b}$ & $655.5 \pm 23.7^{c}$ & $285.0 \pm 12.3^{\mathrm{d}}$ & $62.3 \pm 11.7^{\mathrm{e}}$ & $59.2 \pm 1.2^{\mathrm{e}}$ \\
\hline $\begin{array}{l}\text { Manihot esculenta } \\
\text { (Sweet cassava) }\end{array}$ & $650.4 \pm 39.2^{\mathrm{a}}$ & $520.6 \pm 12.4^{\mathrm{b}}$ & $542.5 \pm 21.9^{\mathrm{c}}$ & $434.8 \pm 14.1^{\mathrm{d}}$ & $67.8 \pm 9.1^{\mathrm{e}}$ & $68.5 \pm 0.3^{\mathrm{e}}$ \\
\hline $\begin{array}{l}\text { Musa spp. } \\
\text { (Plantain-ripe) }\end{array}$ & $963.2 \pm 15.8^{\mathrm{a}}$ & $950.2 \pm 15.1^{\mathrm{a}}$ & $752.5 \pm 18.6^{\mathrm{c}}$ & $787.3 \pm 20.4^{c}$ & $91.3 \pm 7.7^{\mathrm{e}}$ & $57.5 \pm 0.6^{\mathrm{f}}$ \\
\hline $\begin{array}{l}\text { Musa spp. } \\
\text { (Plantain-unripe) }\end{array}$ & $563.3 \pm 25.4^{\mathrm{a}}$ & $450.4 \pm 9.3^{\mathrm{b}}$ & $483.5 \pm 18.2^{\mathrm{c}}$ & $325.8 \pm 13.2^{\mathrm{d}}$ & $96.5 \pm 2.6^{\mathrm{e}}$ & $75.9 \pm 0.5^{\mathrm{f}}$ \\
\hline $\begin{array}{l}\text { Cucurbita pepo } \\
\text { (Pumpkin) }\end{array}$ & $691.4 \pm 20.2^{\mathrm{a}}$ & $670.5 \pm 12.2^{\mathrm{a}}$ & $531.9 \pm 13.5^{\mathrm{c}}$ & $506.8 \pm 18.7^{\mathrm{c}}$ & $77.7 \pm 10.2^{\mathrm{e}}$ & $57.8 \pm 0.1^{\mathrm{f}}$ \\
\hline
\end{tabular}

Values are expressed as mean \pm SEM where $\mathrm{n}=4$. Values with different letter superscripts are significantly different, $\mathrm{P}<0.05, \mathrm{n}=3$. Statistical comparisons were carried out between cooked and uncooked undigested food sample. 
As highlighted in Table 3, in undigested samples, cooking resulted in decreases of $55.1 \%$ in magnesium concentration of Lucea yams, $20 \%$ in sweet cassava and $29.5 \%$ in unripe plantain samples. In assessing digested samples it was observed that cooking resulted in reduced magnesium content of all samples except ripe plantain which recorded an increase of $4.6 \%$ compared to uncooked samples.

Analysis of filtrates of cooked samples showed that the percentage soluble magnesium varied with $7.34 \%$ soluble mineral observed in ripe plantain, $11.43 \%$ in pumpkin, $15.7 \%$ in sweet cassava, $20 \%$ in Lucea yam and $23.37 \%$ in unripe plantain. Uncooked samples recorded soluble magnesium content of $9.51 \%$ in samples of Lucea yam, $12.5 \%$ in sweet cassava, $12.13 \%$ in ripe plantain, $19.88 \%$ in unripe plantain and $14.64 \%$ in samples of pumpkin.

3.4 Zinc

Table 4. Zinc concentrations in digested and undigested samples of four staples in cooked and uncooked states

\begin{tabular}{|c|c|c|c|c|c|c|}
\hline \multirow{3}{*}{ Food Samples } & \multicolumn{6}{|c|}{ Zinc Content (mg/Kg dry weight) } \\
\hline & \multicolumn{2}{|c|}{ Undigested } & \multicolumn{2}{|c|}{ Digested } & \multicolumn{2}{|c|}{ Filtrate } \\
\hline & Uncooked & Cooked & Uncooked & Cooked & Uncooked & Cooked \\
\hline $\begin{array}{l}\text { Dioscorea } \\
\text { rotundata } \\
\text { (Lucea yam) }\end{array}$ & $15.2 \pm 4.7^{\mathrm{a}}$ & $13.1 \pm 0.8^{\mathrm{a}}$ & $12.1 \pm 0.1^{\mathrm{c}}$ & $9.9 \pm 2.1^{\mathrm{c}}$ & $0.8 \pm 0.2^{\mathrm{e}}$ & $1.6 \pm 0.1^{\mathrm{f}}$ \\
\hline $\begin{array}{l}\text { Manihot } \\
\text { esculenta } \\
\text { (Sweet cassava) }\end{array}$ & $9.2 \pm 1.5^{\mathrm{a}}$ & $7.9 \pm 4.3^{\mathrm{a}}$ & $7.9 \pm 0.3^{\mathrm{c}}$ & $6.7 \pm 1.4^{\mathrm{c}}$ & $0.7 \pm 0.1^{\mathrm{e}}$ & $0.4 \pm 0.1^{\mathrm{f}}$ \\
\hline $\begin{array}{l}\text { Musa spp. } \\
\text { (Plantain-ripe) }\end{array}$ & $6.3 \pm 0.4^{\mathrm{a}}$ & $6.4 \pm 0.9^{\mathrm{a}}$ & $5.3 \pm 0.7^{\mathrm{c}}$ & $5.2 \pm 0.1^{\mathrm{c}}$ & $0.5 \pm 0.1^{\mathrm{e}}$ & $0.6 \pm 0.2^{\mathrm{e}}$ \\
\hline $\begin{array}{l}\text { Musa spp. } \\
\text { (Plantain-unripe) }\end{array}$ & $7.4 \pm 0.1^{\mathrm{a}}$ & $6.1 \pm 0.1^{\mathrm{b}}$ & $5.6 \pm 0.9^{c}$ & $5.3 \pm 0.2^{\mathrm{c}}$ & $0.3 \pm 0.1^{\mathrm{e}}$ & $0.3 \pm 0.1^{\mathrm{e}}$ \\
\hline $\begin{array}{l}\text { Cucurbita pepo } \\
\text { (Pumpkin) }\end{array}$ & $13.1 \pm 0.7^{\mathrm{a}}$ & $8.6 \pm 0.2^{\mathrm{b}}$ & $9.1 \pm 1.6^{\mathrm{c}}$ & $6.3 \pm 0.3^{\mathrm{d}}$ & $0.5 \pm 0.1^{\mathrm{e}}$ & $0.6 \pm 0.1^{\mathrm{e}}$ \\
\hline
\end{tabular}

Values are expressed as mean \pm SEM where $\mathrm{n}=4$. Values with different letter superscripts are significantly different, $\mathrm{P}<0.05, \mathrm{n}=3$. Statistical comparisons were carried out between cooked and uncooked undigested food sample.

Assessment of undigested samples showed that only moderate decreases in zinc were observed on cooking. Significant reductions were observed in cooked samples of cooked pumpkin which recorded 61.5 percent reduction compared to uncooked samples.

Modest variations were observed between cooked and uncooked digested samples of sweet cassava ripe plantain and unripe plantain. Digested samples of cooked Lucea yam and pumpkin samples however displayed reductions of $17 \%$ and $27.8 \%$ in zinc compared to uncooked samples.

The percentage soluble zinc as assessed in the filtrate showed that uncooked samples of sweet cassava and ripe plantain contained $9.87 \%$ and $9.68 \%$ soluble zinc while Lucea yam, unripe plantain and pumpkin contained $6.75 \%, 6.87 \%$ and $6.2 \%$ respectively. Assessments of cooked samples showed that percentage soluble zinc varied from $6.59 \%$ in unripe plantain samples to $16.06 \%$ samples of Lucea yam. 
Table 5. Percent soluble minerals in commonly eaten tropical foods

\begin{tabular}{|c|c|c|c|c|c|c|c|c|}
\hline \multirow{3}{*}{ Food Samples } & \multicolumn{8}{|c|}{ Percentage soluble minerals } \\
\hline & \multicolumn{2}{|c|}{ Calcium } & \multicolumn{2}{|c|}{ Iron } & \multicolumn{2}{|c|}{ Magnesium } & \multicolumn{2}{|c|}{ Zinc } \\
\hline & Cooked & ncooked & Cooked & ncooked & Cooked & Uncooked & Cooked & Uncooked \\
\hline $\begin{array}{l}\text { Dioscorea } \\
\text { rotundata } \\
\text { (Lucea yam) }\end{array}$ & 7.27 & 4.64 & 20.22 & 13.78 & 20.00 & 9.51 & 16.06 & 6.75 \\
\hline $\begin{array}{l}\text { Manihot } \\
\text { esculenta } \\
\text { (Sweet cassava) }\end{array}$ & 2.82 & 1.96 & 22.79 & 20.43 & 15.70 & 12.5 & 6.70 & 9.87 \\
\hline $\begin{array}{l}\text { Musa spp. } \\
\text { (Plantain-ripe) }\end{array}$ & 3.76 & 2.44 & 24.50 & 8.92 & 7.34 & 12.13 & 12.42 & 9.68 \\
\hline $\begin{array}{l}\text { Musa spp. } \\
\text { (Plantain-unripe) }\end{array}$ & 12.94 & 11.2 & 37.19 & 14.36 & 23.37 & 19.88 & 6.59 & 6.87 \\
\hline $\begin{array}{l}\text { Cucurbita pepo } \\
\text { (Pumpkin) }\end{array}$ & 6.32 & 4.36 & 17.48 & 13.48 & 11.43 & 14.64 & 9.50 & 6.20 \\
\hline
\end{tabular}

Table 5 shows percentage soluble minerals in commonly consumed tropical foods. A general overview shows that higher percentages of soluble minerals were observed in cooked food samples compared to uncooked samples. Soluble magnesium concentrations were however higher in uncooked samples of ripe plantain and pumpkin compared to cooked samples. Uncooked samples of sweet cassava and unripe plantain also displayed higher percentages soluble zinc compared to cooked samples. Higher percentages of soluble magnesium and iron were generally observed in the food samples compared to soluble calcium and zinc.

\section{Discussion}

Calcium has important functions in membrane permeability, neuromuscular excitability, neurotransmitter release, blood coagulation and is also involved in numerous other metabolic pathways (Davis et al., 2001). In light of its importance to mammalian metabolism, assessments of its concentrations in commonly consumed staples, along with factors that may affect its availability from such foods, are of importance. Calcium concentration of unprocessed food samples varied considerably with the highest amounts recorded in samples of sweet cassava; only a $3 \%$ reduction was observed after cooking. This bears some significance as production and consumption of sweet cassava in many tropical countries is currently on the decline. This research however shows that in light of its high calcium content, increased cassava production should be encouraged in order to address dietary deficiencies of this mineral. Appreciable levels of calcium were also observed in samples of ripe plantain as well as pumpkin. Samples of unripe plantain recorded significantly lower calcium compared to ripe plantain and this is in line with previous researchers who noted that concentration of some minerals increased in plantain on ripening (Izonfuo \& Omuaru, 1988). This suggests that in addition to its vitamin content, the plantain fruit in the ripe stages can also be exploited for its calcium content. Further studies related to the ripening stage at which calcium and other minerals are present in highest quantities are needed as this will help to maximize the nutritional potential of this underutilized food.

Following sample digestion, mineral content of the residues and filtrates were assessed with the concentration in filtrate representing the soluble mineral portion. The mineral content in the filtrates represents the soluble portion of minerals hence the portion available for absorption (Skibniewska, 2002). Assessments of the digested residues showed that cooking resulted in reduced calcium content of the food samples assessed. This may be attributed to the method of cooking as mineral loss may occur whenever food samples are boiled in large volumes of water; resulting in mineral loss to the boiling medium. The observed loss of minerals from staple crops after boiling was also observed previously (Ebuehi, 2005; Dilworth et al., 2007). Mineral loss to water medium may however be beneficial in cases where the liquid is retained for consumption e.g. in preparation of stews or soups. In these scenarios, minerals lost from the food sample are still available for consumption. Assessment of sample filtrates showed that soluble calcium concentrations were generally higher in cooked samples compared to uncooked ones. This was expected as cooking increases the release of minerals from foods by mainly reducing antinutrient 
levels in the food samples (Lewu et al., 2009). The data showed that, except for unripe plantain with 12.9\% soluble calcium, total soluble calcium of all other crops was less than $10 \%$. One reason for low bioavailability of minerals from staple foods may be due to insufficient mineral assimilation due to harvesting of food crops before they are fully mature. For this study, we theorise that the presence of tannins, phytates, oxalates and other mineral-chelating factors, in addition to their possible resistance to the cooking procedure employed, may have contributed to reduced bioavailability of calcium. Future studies aimed at assessing the effects of different cooking methods on calcium bioavailability would be useful. Further work inclusive of in vivo assays are useful in assessing mineral bioavailability hence these assays along with solubility studies should provide a more complete assessment of essential mineral bioavailability as opposed to solubility studies alone.

Iron is an important micronutrient required for formation and functioning of haemoglobin, myoglobin, some antioxidant enzymes as well as components of the electron transport chain (Guyton \& Hall, 1996). While it is an important mineral, it is absorbed slowly and may have negative effects in high dosages. Appreciable levels of iron were observed in undigested food samples with some samples recording no significant lowering of iron content following cooking. Following digestion, all sample residues recorded reduced iron content in cooked samples compared to uncooked ones. Assessment of soluble iron in cooked samples shows that its bioavailability based on soluble iron content ranged from $17.5 \%$ in pumpkin samples to $37.19 \%$ in samples of unripe plantain. This data suggests that the food crops analysed may serve as important sources of dietary iron. This is a significant finding since production of these crops traditionally grown in the Caribbean region have seen steady decline over time in favour of imported staples which may be cheaper than locally grown staples. This data therefore argues for refocused attention to increased production of traditionally grown staples that are capable of fulfilling macro and micronutrient dietary requirements. Importantly, this research found that daily consumption of $1.1 \mathrm{Kg}$ of unripe plantain is enough to satisfy both United States of America and United Kingdom daily recommended iron intake $15 \mathrm{mg}$ and $14 \mathrm{mg}$ respectively. It is important to note however that bioavailability of iron from these samples is not an indication of the amount that is eventually absorbed by the body. Only in vivo studies can confirm the amount of minerals absorbed since other factors including molecular form of the mineral, as well as the presence of mineral chelating factors present within foods, may influence the amount of minerals absorbed. Previous studies however show that prior to consumption, appropriate processing of starchy foods commonly consumed in the tropics will reduce antinutrient content to levels that will not significantly affect mineral availability (Omoruyi et al., 2007; Osagie, 1998). Other factors including nutritional status and vitamin $\mathrm{C}$ intake may also affect iron absorption and usage.

Magnesium is the most abundant divalent cation in the body and is an important cofactor in more than three hundred enzymatic reactions, with its deficiency affecting virtually every organ in the body (Baler, 1991, 1992). Assessment of digested samples showed that there were general reductions in magnesium content after cooking and this may be attributed to mineral loss to the cooking medium. Soluble magnesium content were low compared to the concentrations in undigested samples, however the concentrations in cooked samples were enough to satisfy $20 \%$ of recommended daily allowance (of about $400 \mathrm{mg}$ ) for a adult (Institute of medicine, 1999). Results from this study showed that magnesium content of the staple crops assessed in this study are higher than concentrations of those cultivated elsewhere (Osagie, 1998; Adeniji \& Tenkouano, 2008; Thomas \& Oriaku, 2010). No data on magnesium content of the Lucea yam cultivar was found; hence this paper may be the first contribution to the literature in that regard. Although literature has information on magnesium content of some staples, data is sparse on actual bioavailability of this mineral from these staples commonly consumed in the tropics. As a result, further comparative studies on bioavailability of magnesium from samples grown elsewhere are needed. Since magnesium is of critical importance to normal metabolism, further research aimed at ascertaining its bioavailability from commonly consumed staples and the factors that may be antagonistic to its availability is needed.

Zinc plays significant roles in animal metabolism as it is important for neuronal development, maintenance of epithelial structures, immune cell functioning and preservation of cardiac function (Soinio et al., 2007; Haase \& Rink, 2009). The content and bioavailability in commonly consumed staples should therefore serve as an important addition to the body of knowledge available to food industry interests. Data related to zinc content of sample filtrates indicated that cooking did not significantly enhance bioavailability of zinc from the food samples assessed. Research shows that starchy tubers are not known to be excellent sources of zinc due to the presence of mineral chelating factors including phytates within these food crops. This research however showed that all the samples assessed contain appreciable levels of soluble zinc. In addition to animal protein, which serves as the main sources of zinc, we propose that the staple crops assessed in this study may also serve as important sources of dietary zinc. This and previous studies (Dilworth et al., 2007; Dilworth et al., 2012) show that appreciable 
levels of zinc are found in commonly eaten staples, however, as with other minerals, we contend that bioavailability of zinc and factors affecting bioavailability from these foods are more important parameters to assess as opposed to mineral content only. It is notable that while data exists regarding mineral content of food samples, that there is a scarcity of data regarding their bioavailability from the samples selected for this study.

\section{Conclusion}

While data exists regarding mineral content of foods, there is a paucity of data regarding mineral bioavailability from commonly consumed tropical staples. This paper is significant as it highlights bioavailability of essential minerals from commonly consumed staples as opposed to mineral content only. While the staple crops assessed are always promoted for their starch content, this research suggests that they may also serve as important sources of some essential minerals. This bears some significance as the staple crops assessed may play important roles in reducing the incidences of reported mineral deficiencies in the Caribbean and other regions of the tropics. Data from this study is also of relevance to developers of highly nutritious nutraceutical products from locally grown staple food crops. Research related to methods of improving mineral availability from commonly consumed staples, while maintaining palatability, is required since these food samples make up a large percentage of the diets of many residents in tropical and subtropical areas. This research shows that regional agricultural interests should re-evaluate the reasons for the decline in production of some foods assessed in this study in an attempt to revamp production, thereby increasing their output. This is significant as the food samples assessed are highly nutritious, easy to cultivate and may be important contributors in alleviating any impending food crisis. We contend that in vivo studies provide more accurate data regarding mineral bioavailability as opposed to estimated correlation between solubility and bioavailability. Data from in vivo studies are therefore needed for comparison.

\section{Acknowledgements}

The authors wish to express gratitude to the technical staff in the department of Chemistry UWI Mona and to Ms. Sannette Hall for editorial assistance. The authors also wish to thank the department of graduate studies and research for financial assistance.

\section{References}

Adeniji, A. T., \& Tenkouano, A. (2008). Effect of processing on the proximate mineral and pasting properties of whole flour made from some new plantain and banana hybrids pulp and peel mixture. Journal of Tropical Agriculture, Food, Environment and Extension (NGA), 7(2), 99-105.

Akinmoladun, A. C., Ibukun, E. O., Afor, E., Akirinlola, B. L., Onibon T. R., Akinboboye, A. O., ... Farombi, E. O. (2007). Chemical constituents and antioxidant activity of Alstonia boonei. African Journal of Biotechnology, 6(10), 1197-1201.

Amusa, N. A., Adegbite, A. A., Muhammed, S., \& Baiyewu, R. A. (2003). Yam diseases and their management in Nigeria. African Journal of Biotechnology, 2(12), 497-502.

Association of Official Analytical Chemists. (2000). Official methods of analysis (17th ed.). Gaithersburg, Maryland, USA: Association of Official Analytical Chemists, Inc.

Ayodele, O., \& Godwin, E. (2010) Glycemic indices of processed unripe plantain (Musa paradisiaca) meals. African Journal of Food Science, 4(8), 514-521.

Beckford, C., Campbell, D., \& Barker, D. (2011). Sustainable food production systems and food security: Economic and environmental imperatives in yam cultivation in Trelawny, Jamaica. Sustainability, 3, 541-561. http://dx.doi.org/10.3390/su3030541.

Dilworth, L., Omoruyi, F. O., \& Asemota, H. (2007). In vitro availability of some essential minerals in commonly eaten processed and unprocessed Caribbean tuber crops. Biometals, 20, 37-42. http://dx.doi.org/10.1007/s10534-006-9012-4

Dilworth, L., Brown, K., Wright, R., Oliver, M., Hall. S., \& Asemota, H. (2012). Antioxidants, minerals and bioactive compounds in tropical staples. African Journal of Food Science and Technology, 3(4), 90-98.

Ebuehi, O. A. T. (2005). Phytochemical, nutritive and anti-nutritive composition of cassava (Manihot esculenta L) tubers and leaves. Nigerian Food Journal, 23, 40-46.

Essono, G., Ayodele, M., Akoa, A., Foko, J., Gockowski, J., \& Olembo, S. (2008). Cassava production and processing characteristics in southern Cameroon: An analysis of factors causing variations in practices between farmers using Principal Component Analysis (PCA). African Journal of Agricultural Research, 3(1), 49-59. 
Etebu, E., \& Young-Harry, W. (2011). Review: Control of black Sigatoka disease: Challenges and prospects. African Journal of Agricultural Research, 6(3), 508-514. http://dx.doi.org/10.5897/AJAR10.223

Fairweather-Tait, S. J. (1992). Bioavailability of trace elements. Food Chemistry, 43, 213-217. http://dx.doi.org/10.1016/0308-8146(92)90176-3

Guyton, A. C., \& Hall, J. E. (1996). Textbook of Medical Physiology (9th ed.). Philadelphia, USA: WB Saunders.

Haase, H., \& Rink, L. (2009). The immune system and the impact of zinc during aging. Immunity and Ageing, 6, 9. http://dx.doi.org/10.1186/1742-4933-6-9

Honfo, F. G., Tenkouano, A., \& Coulibaly, O. (2011). Banana and plantain-based foods consumption by children and mothers in Cameroon and Southern Nigeria: A comparative study. African Journal of Food Science, $5(5), 287-291$.

Hong, L. H. (2005). Effect of pumpkin extracts on tumor growth inhibition in S180-bearing mice. Practical Preventative Medicine, 12, 745-747.

Ikeda, S. (1990) Dietary zinc and the zinc components in various foods subjected to in vitro enzymatic digestion. Journal of the Science of Food and Agriculture, 53, 229-234. http://dx.doi.org/10.1002/jsfa.2740530210

Institute of Medicine. Food and Nutrition Board. (1999). Dietary reference intakes: calcium, phosphorus, magnesium, vitamin $d$ and fluoride. Washington, DC: National Academy Press.

Izonfuo, W. A. L., \& Omuaru, V. O. T. (1988). Effect of ripening on the chemical composition of plantain peels and pulps (Musa paradisiaca). Journal of the Science of Food and Agriculture, 45, 333-336. http://dx.doi.org/10.1002/jsfa.2740450407

Lewu, M. N., Adebola, P. O., \& Afolayan, A. J. (2009). Effect of cooking on the mineral and antinutrient contents of the leaves of seven accessions of (Colocasia esculenta L.) Schott growing in South Africa. Journal of Food Agriculture and Environment, 7(3\&4), 359-363.

Makni, M., Fetoui, H., Gargouri, N. K., Garoui, E. M., Jaber, H., Makni, J., Jaber, H., \& Makni, H. (2008). Hypolipidemic and hepatoprotective effects of flax and pumpkin seed mixture rich in $\omega-3$ and $\omega-6$ fatty acids in hypercholesterolemic rats. Food and Chemical Toxicology, 46, 3714-3720. http://dx.doi.org/10.1016/j.fct.2008.09.057

Ndoro, O. F., Madakadze, R. M., Kageler, S., \& Mashingaidze, A. B. (2007). Indigenous knowledge of the traditional vegetable pumpkin (Cucurbita maxima/moschata) from Zimbabwe. African Journal of Agricultural Researcg, 2(12), 649-655.

Oboh, G. (2005). Isolation and characterization of amylase from fermented cassava (Manihot esculenta Crantz) wastewater. African Journal of Biotechnology, 4(10), 1117-1123.

Ogunladem, I., Olaifa, O., Adeniran, O. A., \& Ogunlade, A. O. (2011). Effect of domestic processing on the amino acid profile of Dioscorea rotundata (White yam). African Journal of Food Science, 5(1), 36-39.

Omoruyi, F. O., Dilworth, L., \& Asemota, H. N. (2007). Antinutritional factors zinc and calcium in some Caribbean tuber crops and the effecting of boiling and roasting. Nutrition and Food Science, 37(1), 37-42. http://dx.doi.org/10.1108/00346650710726904

Osagie, A. U. (1998). Antinutritional factors. In A. U. Osagie \& O. U. Eka (Eds.), Nutritional quality of plant foods (pp. 221-224). Post Harvest Research Unit, Department of Biochemistry, Benin City, Nigeria: Ambik Press.

Skibniewska, K. A., Kozirok, W., Fornal, L., \& Markiewicz, K. (2002). In vitro availability of minerals from oat products. Journal of the Science of Food and Agriculture, 82, 1676-1681. http://dx.doi.org/10.1002/jsfa.1243

Soinio, M., Marniemi, J., Laakso, M., Pyorala, K., Lehto, S., \& Ronnemaa, T. (2007). Serum zinc level and coronary heart disease events in patients with type 2 diabetes. Diabetes Care, 30(3), 523-528. http://dx.doi.org/10.2337/dc06-1682

Thomas, A. O., \& Oriaku, N. J. (2010). Nutrient composition and contribution of noodles (abacha) and local salad from cassava (Manihot spp) to nutrient intake of Nigerian consumers. African Journal of Food Science, $4(7), 422-426$. 